\title{
SCENIC BEAUTY ESTIMATION ANALYSIS OF SARA BESAR ISLAND FOR THE DEVELOPMENT OF COASTAL ECOTOURISM IN TALAUD ISLANDS DISTRICT
}

\author{
Joyce Ch. Kumaat ${ }^{1}$, Kalvin S. Andaria ${ }^{2}$, Hilda F. Oroh ${ }^{3}$ \\ ${ }^{1,3}$ Geography, Faculty of Social Science, Universitas Negeri Manado \\ ${ }^{2}$ Geography Education, Faculty of Social Science, Universitas Negeri Manado \\ E-mail: joykekumaat@unima.ac.id
}

\begin{abstract}
This study aims to determine the potential of coastal areas in ecotourism development through a spatial approach using Scenic Beauty Estimation (SBE) analysis. The benefits related to the use of geographic information technology will conceptually provide the right solution for planning and regional development in ecotourism development. Activities carried out include collecting data in the field related to physical and non-physical factors in coastal areas through surveys and mapping, then analyzing data in a Scenic Beauty Estimation (SBE) and designing geographic information systems in the form of mapping on 1) physical, artistic potential, and tourist activities, 2) accessibility (transportation), 3) information and accommodation services. The contribution of this research is to provide information and input for the government to facilitate and determine the planning and development of ecotourism in the coastal area of Talaud Regency on the island of Sara. It can increase regional or regional income, participation, and support in managing and utilizing coastal regions.
\end{abstract}

Keywords: Sara Island; Scenic; Beauty; Estimation.

\section{A. INTRODUCTION}

Indonesia is the biggest archipelago country globally (Patrianti, Bajari, Agustin, \& Bakti, 2020). It consists of 17,508 islands with a coastline of 81,000 $\mathrm{km}$, about 3.1 million $\mathrm{km} 2$ (0.3 million $\mathrm{km}$ of territorial waters and 2.8 million $\mathrm{km} 2$ of Indonesian waters), or $62 \%$ of its territorial area (BIG, 2015; Muhamad, 2014). Some of these resources have not been utilized optimally (Kumaat \& Wullur, 2017); for example, the sustainable potential of marine fishery resources of 6.7 tone's/year has only been utilized as much as 48\% (CEA, 2018; DLPF - The David and Lucile Packard
Foundation., 2015; IDA, 2020). Humans can enjoy a landscape's beauty by observing the view through the five senses, namely sight (Morin, 2009; Zhang et al., 2018). Landscape can provide different psychological perceptions and feelings and present symbolic values (Fadlin \& Marfai, 2016; Khakhim, Soedharma, Mardiastuti, Siregar, \& Boer, 2008). he need for natural landscape aesthetics to fulfill emotional sensations becomes an impetus for finding natural objects with high aesthetic qualities (Fadlin \& Marfai, 2016). The aesthetic quality of a landscape or landscape is an 
indicator of ecological observations, especially in conservation action (Farizal, Harahaf, \& Zahra, 2020). The formulation of aesthetic policies brings a sound understanding of environmental problems (Fadlin \& Marfai, 2016).

This analysis of visual landscape preferences uses the Scenic Beauty Estimation (SBE) method proposed by Daniel \& Boster (1976). Initially, the SBE method was developed to assess a landscape for forestry tourism development visually (Daniel \& Schroeder, 1979). Based on the SBE method used to determine the terrain visually, coastal areas also have a potential landscape developed and managed as a tourist attraction (Daniel \& Boster, 1976; Daniel \& Schroeder, 1979; Gandy \& Meitner, 2007).

Talaud Islands Regency (Koondoko, Darma Putra, \& Paturusi, 2017; Wijayanto, Triarso, Nur Taufiq, \& Sugianto, 2019) has so many tourism potentials that have not been managed by related parties in the world of tourism, namely the regional government, the Talaud Regency tourism office (Wijayanto et al., 2019). Sara Island has exclusive tourism potential as well as leading tourism objects in the Talaud community (Riansyah, Aliya, \& Nahumariri, 2019).

Based on researchers' observations, that the local government did not give the management of the island of Sara as a tourism object in Talaud District enough attention. Lots of rubbish scattered along the ring road and on the beach is overlooked. There are also simple houses built by the government as resting places that are not well maintained, and some do not have necessary facilities such as seating. Sources of clean water for sanitation purposes are still limited. The absence of outstanding transportation facilities to Sara Island is also an obstacle for local tourists to travel on this island.

Following the existing problems, this research is limited to Visual Preference Analysis Sara Island Landscape Large Talaud Islands. The purpose is to analyze the beauty of the landscape on Talaud Islands Sara Besar's island using Visual Preference Analysis.

\section{B. MATERIALS AND METHODS}

The visual analysis method that can be used in this research is the Scenic Beauty Estimation (SBE) method proposed by Daniel \& Boster, (1976) and Khakhim et al., (2008). Some method used SBE (Daniel \& Boster, 1976; Khakhim et al., 2008): of the reasons why this is the:

- Many visual studies have used the SBE method to calculate their visual value because the SBE procedure is known to be effective and reliable.

- The initial development of the SBE 
method was to assess a landscape for forestry tourism development visually. Based on the SBE method used to visually determine the landscape, where the coastal area also has a potential landscape to be developed and managed as a coastal tourism area, the SBE method is used by adjusting the conditions and types of landscape in the coastal zone.

- The SBE method used is to assess the coastal landscape.

The steps taken in determining the SBE value are:

1. Determining the point of observation and taking photos, the end of compliance in taking pictures determines the coastal landscape characteristics in each coastal typology as a unit of analysis.

2. Photo selection, the photos presented to respondents, result from all the images taken and consider the most representative of the diversity of scenery along Sara Island.

3. Assessment by respondents, Respondents selected in this study were the people of Bitunuris village, Salibabu sub-district, Talaud district, who had seen and visited the island of Sara Besar. Each photo was distributed in the form of a questionnaire and immediately assessed by the respondent. Respondents rated each photo shared by giving a score of 1 to 10 , where a score of 1 indicates a very bad or least liked to score, and a value of 10 is a very good or most appreciated value.

4. Calculation of the SBE value, the stages of calculating visual values using the SBE method begin with data tabulation, analysis of the frequency of each score (F), calculation of the cumulative frequency $(\mathrm{CF})$, and cumulative probabilities $(\mathrm{CP})$. Then the $\mathrm{z}$ value is determined. The average $\mathrm{z}$ value obtained from each photo included in the SBE formula (Daniel \& Boster, 1976; Khakhim et al., 2008):

$$
\mathrm{SBE}_{\mathrm{x}}=\left(\mathrm{Z}_{\mathrm{x}}-\mathrm{Z}_{\mathrm{o}}\right) \mathrm{x} 100
$$

Where,

$$
\begin{aligned}
& \mathrm{SBE}_{\mathrm{x}}=\text { the estimated value of the } \mathrm{x}^{\text {th }} \\
& \text { value of the landscape beauty } \\
& Z_{x}=\mathrm{z} \text { average value for the } \mathrm{x} \text { - } \\
& \text { landscap } \\
& Z_{0}=\text { average value of a particular } \\
& \text { landscape as standard. }
\end{aligned}
$$

The variable in this st udy is a single variable or mono-variable, namely analyzing the landscape or condition of the Sara Besar Island Coast, Talaud Islands Regency. The indicator in this study is the preference for the landscape on the coast of Sara Besar Island.

\section{RESULTS AND DISCUSSION}

\section{Overview Research Area}

Overview of Sara Island large and small, with fine white sand. Sara Island, which has an area of $2.3 \mathrm{~km}^{2}$ is a paradise for tourists who like panoramic views of white sandy beaches. Talaud Islands Regency is a maritime area with a sea area of about $37,800 \mathrm{~km}^{2}$ or $95.24 \%$ and a land area of $1,251.02 \quad \mathrm{~km}^{2} \quad(3.76 \%)$. 
Astronomically, this island located at $03^{0}$ 56'34" North Latitude and $126^{\circ} 42^{\prime} 49^{\prime \prime}$ East Longitude with the following boundaries: To the west is Salibabu Island; To the north is Sara Kecil Island; To the east is the Maluku Sea and to the south is Salibabu Island, precisely Lirung City as the second largest city after the capital city of Melonguane Regency (Figure 1).

The island of Sara Besar can be accessed from Melonguane and Lirung by using motorboats owned by fishermen. The trip from Lirung City to Sara Besar Island can be reached in about 15 minutes
(Figure 2). The natural conditions of Sara Besar Island, such as coral reef ecosystems, indicate that the state of coral reefs on the island of Sara Besar is still relatively good, although in terms of area of dead coral is more dominant with 15.17 ha compared to live coral which is 8.77 ha, mangrove ecosystems only around 2.83 ha while the seagrass ecosystem 68.43 ha is founded on the island's eastern side and some on its western part. With this area, it can protect Sara Besar Island from abrasion.

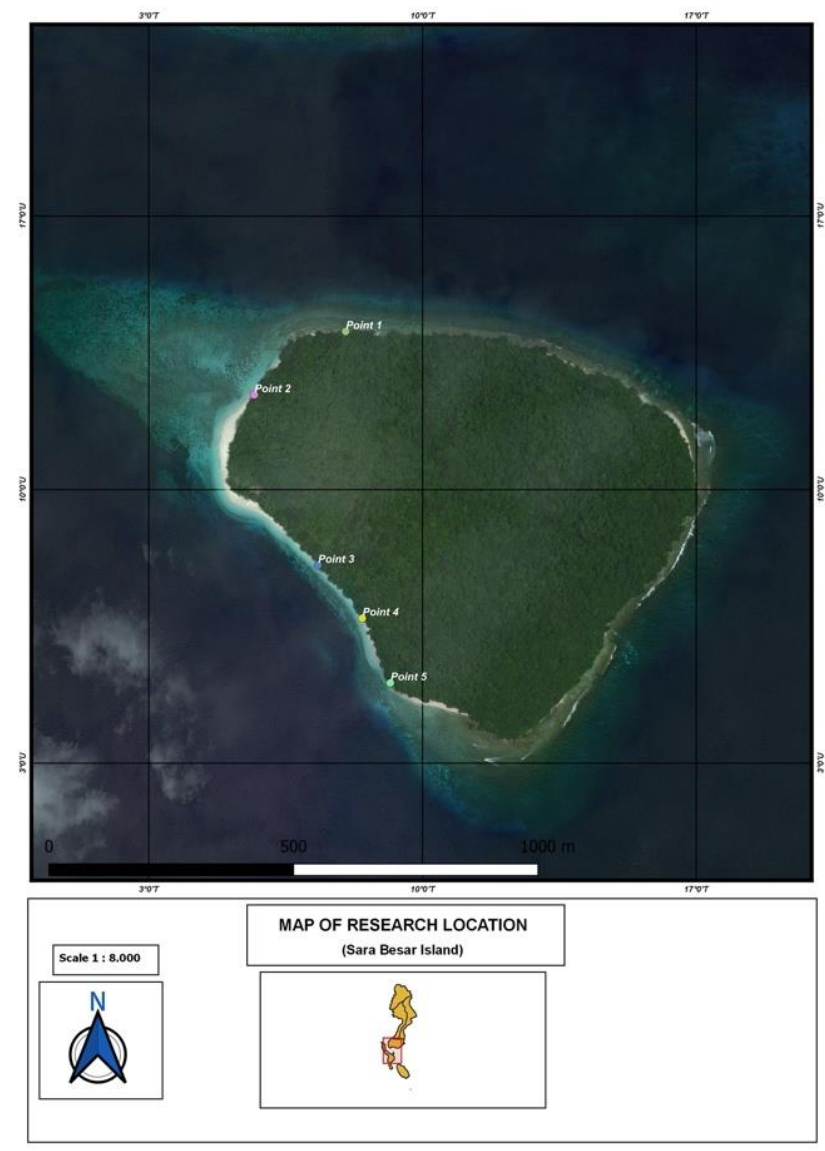

Figure 1. Map of Research Location Sara Besar Island 

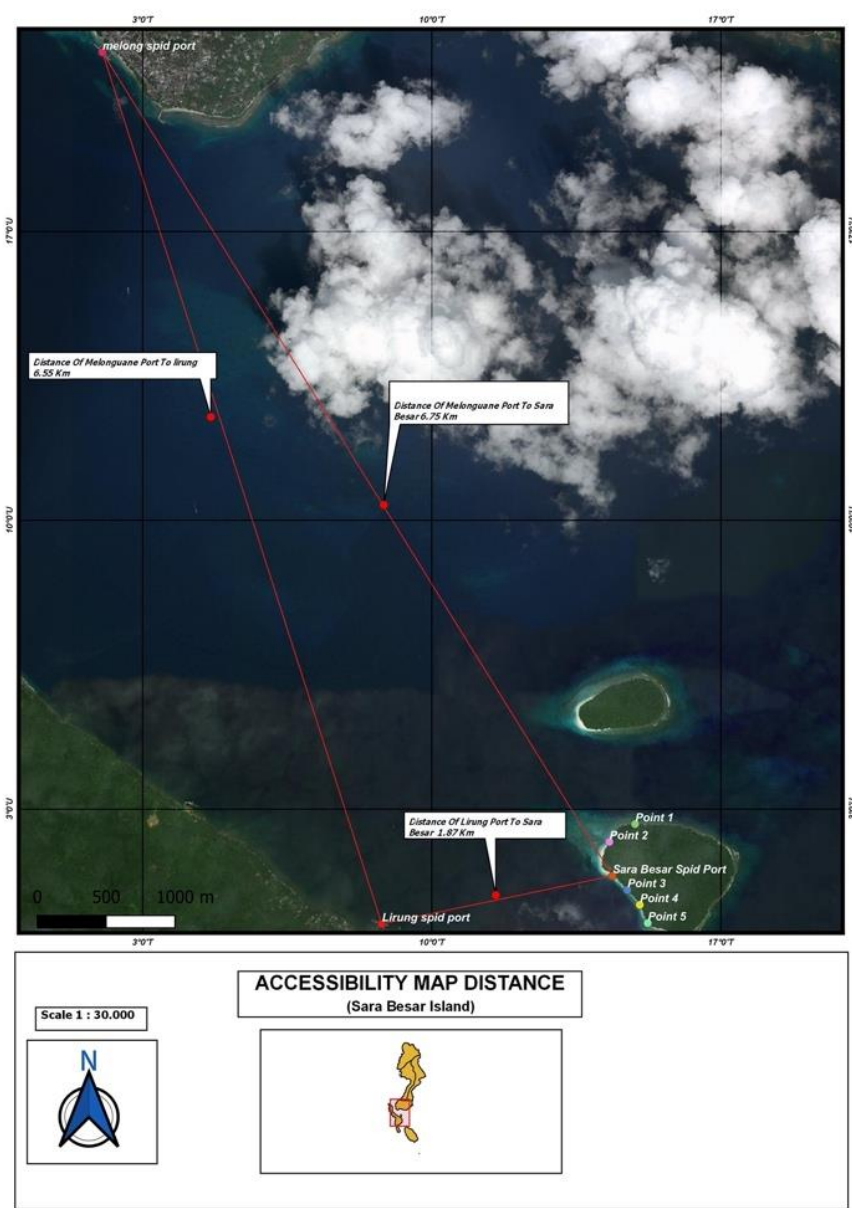

Figure 2. Map of Accessibility Sara Besar Island

The research procedure used refers to the stages of determining the SBE Scenic Beauty Estimation value, namely determining the point of observation and taking photos, selecting photos, assessing respondents, and calculating the SBE value.

1) Determination of observation points and photo taking

The determination of observation points is based on the potential beauty of the coastal landscape of the island of Sara. Because this island has a small land area, so few photos are taken. Below is a snapshot of five (5) observation points that have the potential for beautiful landscapes.

2) Photo selection

Several photographs have taken representing potential beauty points in the coastal landscape of the island of Sara. The photos were then selected to use the respondent's assessment format to obtain an overview of each point's assessment (table 1). 
3) Calculation of the SBE value

The calculation of visual values using the SBE method begins with data tabulation to calculate the frequency of each score (f), the cumulative frequency (cf), and cumulative probabilities (cp). The $\mathrm{z}$ value for each value of $\mathrm{cp}$ is further determined where specifically for the value of $\mathrm{cp}=1.00$ or $\mathrm{cp}=(\mathrm{z}=$ $\pm ¥)$ the calculation formula is used $\mathrm{cp}=1-1 /(2 \mathrm{n})$ or $\mathrm{cp}=1 /(2 \mathrm{n})$ (Khakhim et al., 2008). The SBE value calculation at each point taken in Sara Island using the above equation is presented in the Tables $2-5$.

From the assessment with photos showing that almost all points show extraordinary beauty, the white sand along the coast provides a panoramic view that differentiates it from other coastal environments. This condition indicates that Sara Besar's island landscape is very dominant, which is white sand and sloping coastal land, as shown in the photo with sampling points 1-5.

Table 1. Assessment of scenic beauty estimation at each point of observation

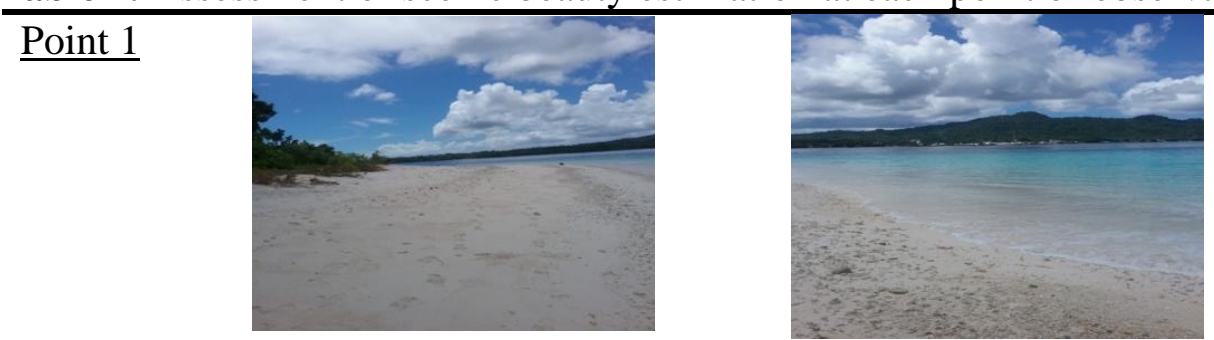

Description The morphology of the beach shows the physical condition of the beach. The landscape is sloping, white sand, and the size of the sediment grains is fine.

Point 2
Morphologically, the beach shows a sloping landscape, white and fine
sand, and there are an island icon and a beach volleyball court.




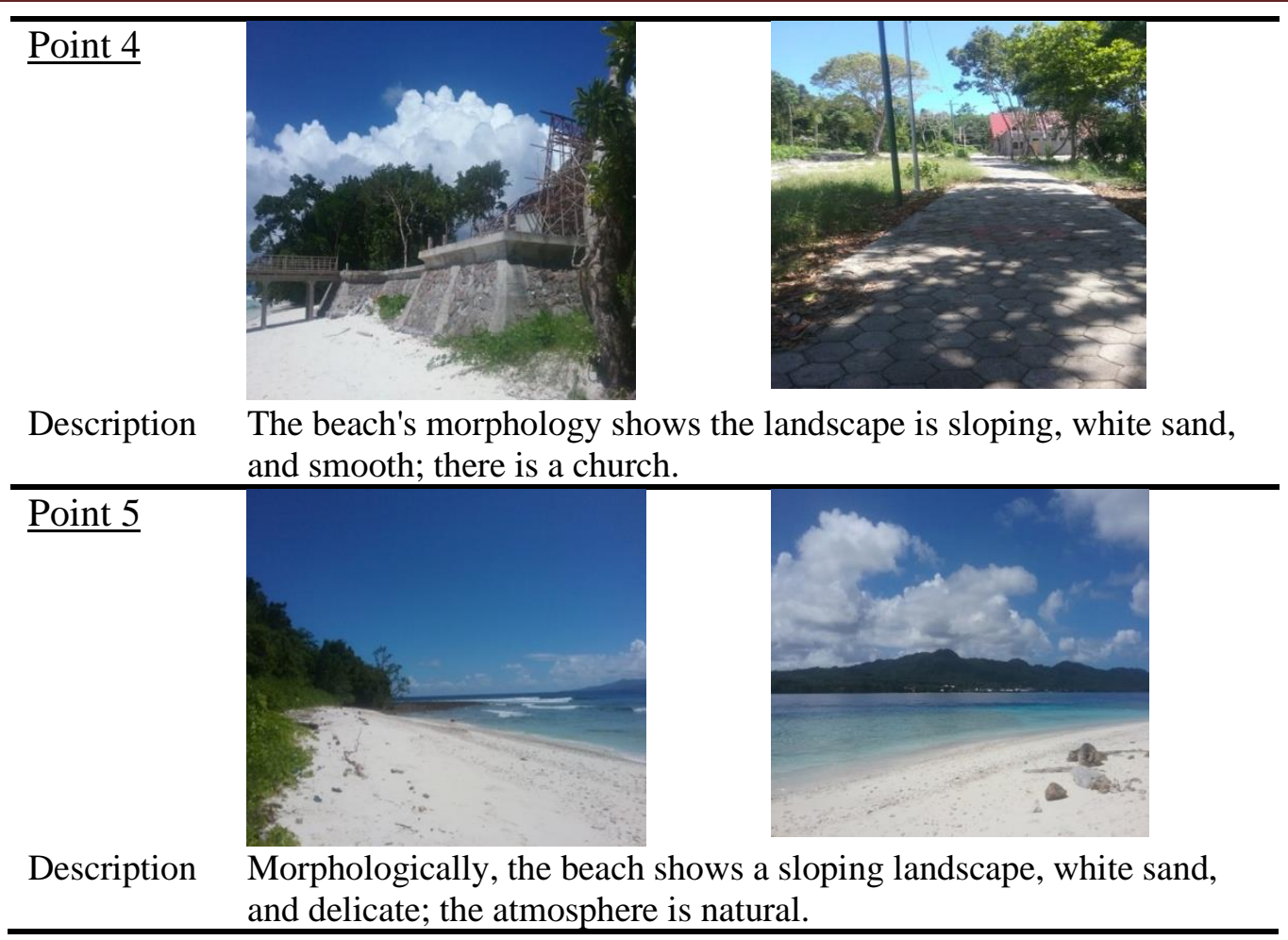

Source: Data Analysis 2020

Table 2. SBE value calculation results at the point I

\begin{tabular}{|c|c|c|c|c|}
\hline Score & F & CF & CP & $\mathbf{Z}$ \\
\hline 1 & 0 & 50 & 1 & - \\
\hline 2 & 0 & 50 & 1 & 2 \\
\hline 3 & 0 & 50 & 1 & 2 \\
\hline 4 & 7 & 50 & 1 & 2 \\
\hline 5 & 6 & 43 & 0.86 & 1.72 \\
\hline 6 & 20 & 37 & 0.74 & 1.48 \\
\hline 7 & 8 & 17 & 0.34 & 0.68 \\
\hline 8 & 5 & 9 & 0.18 & 0.36 \\
\hline 9 & 4 & 4 & 0.08 & 0.16 \\
\hline 10 & 0 & 0 & 0 & 0 \\
\hline \multicolumn{5}{|c|}{$\sum$ Z } \\
\hline \multicolumn{5}{|c|}{ SBE $=\mathbf{1 . 0 4}-(-\mathbf{0 , 7 1}) \times \mathbf{1 0 0}=\mathbf{1 7 5}$} \\
\hline
\end{tabular}

Source: Primary data analysis 2020 
Table 3. SBE value calculation results at the point 2

\begin{tabular}{|c|c|c|c|c|}
\hline Score & $\mathbf{F}$ & $\mathbf{C F}$ & $\mathbf{C P}$ & $\mathbf{Z}$ \\
\hline 1 & 0 & 50 & 1 & - \\
\hline 2 & 0 & 50 & 1 & 2 \\
\hline 3 & 0 & 50 & 1 & 2 \\
\hline 4 & 0 & 50 & 1 & 2 \\
\hline 5 & 0 & 50 & 1 & 2 \\
\hline 6 & 1 & 50 & 1 & 2 \\
\hline 7 & 7 & 49 & 0.98 & 1.96 \\
\hline 8 & 17 & 42 & 0.84 & 1.68 \\
\hline 9 & 19 & 25 & 0.5 & 1 \\
\hline 10 & 6 & 6 & 0.12 & 0.24 \\
\hline \multicolumn{4}{|c|}{$\sum \mathrm{Z}$} & 14.88 \\
\hline \multicolumn{4}{|c|}{$\mathrm{Z}$} & 1.48 \\
\hline \multicolumn{5}{|c|}{ SBE $=1.48-(-0,71) \times 100=219$} \\
\hline
\end{tabular}

Source: Primary data analysis 2020

Table 4. SBE value calculation results at the point 3

\begin{tabular}{|c|c|c|c|c|}
\hline Score & F & CF & CP & $\mathbf{Z}$ \\
\hline 1 & 0 & 50 & 1 & - \\
\hline 2 & 0 & 50 & 1 & 2 \\
\hline 3 & 0 & 50 & 1 & 2 \\
\hline 4 & 0 & 50 & 1 & 2 \\
\hline 5 & 0 & 50 & 1 & 2 \\
\hline 6 & 1 & 50 & 1 & 2 \\
\hline 7 & 10 & 49 & 0.98 & 1.96 \\
\hline 8 & 15 & 39 & 0.78 & 1.56 \\
\hline 9 & 16 & 24 & 0.48 & 0.96 \\
\hline 10 & 8 & 8 & 0.16 & 0.32 \\
\hline \multicolumn{5}{|c|}{$\sum Z$} \\
\hline Z & & 14.8 \\
\hline
\end{tabular}

Source: Primary data analysis 2020 
Table 5. SBE value calculation results at the point 4

\begin{tabular}{|c|c|c|c|c|}
\hline Score & F & CF & CP & Z \\
\hline 1 & 0 & 50 & 1 & - \\
\hline 2 & 0 & 50 & 1 & 2 \\
\hline 3 & 0 & 50 & 1 & 2 \\
\hline 4 & 1 & 50 & 1 & 2 \\
\hline 5 & 2 & 49 & 0.98 & 1.96 \\
\hline 6 & 2 & 47 & 0.94 & 1.88 \\
\hline 7 & 14 & 45 & 0.9 & 1.8 \\
\hline 8 & 20 & 31 & 0.62 & 1.24 \\
\hline 9 & 9 & 11 & 0.22 & 0.44 \\
\hline 10 & 2 & 2 & 0.04 & 0.08 \\
\hline \multicolumn{5}{|c|}{$\sum$ Z } \\
\hline \multicolumn{6}{|c|}{ SBE = 1.34 -(-0,71) $\mathbf{1 0 0}=\mathbf{2 0 5}$} \\
\hline
\end{tabular}

Source: Primary data analysis 2020

Table 6. SBE value calculation results at point 5

\begin{tabular}{|c|c|c|c|c|}
\hline Score & $\mathbf{F}$ & $\mathbf{C F}$ & $\mathbf{C P}$ & $\mathbf{Z}$ \\
\hline 1 & 0 & 50 & 1 & - \\
\hline 2 & 0 & 50 & 1 & 2 \\
\hline 3 & 0 & 50 & 1 & 2 \\
\hline 4 & 0 & 50 & 1 & 2 \\
\hline 5 & 0 & 50 & 1 & 2 \\
\hline 6 & 1 & 50 & 1 & 2 \\
\hline 7 & 5 & 49 & 0.98 & 1.96 \\
\hline 8 & 12 & 44 & 0.88 & 1.76 \\
\hline 9 & 18 & 32 & 0.64 & 1.28 \\
\hline 10 & 14 & 14 & 0.28 & 0.56 \\
\hline \multicolumn{4}{|c|}{$\sum \mathrm{Z}$} & 15.56 \\
\hline \multicolumn{4}{|c|}{$\mathrm{Z}$} & 1.55 \\
\hline \multicolumn{5}{|c|}{ SBE $=1.55-(-0,71) \times 100=226$} \\
\hline
\end{tabular}

Source: Primary data analysis 2020

The SBE value for point 1 to point 5 is further confirmed in the value category table above, respectively, with 175,219 , 219, 205, and 226. The lowest SBE value is point 1 , namely 175 , while the highest is point 5 is 226 . Based on this value, the five landscape points taken as samples are categorized as high SBE values. Referring to the SBE value calculation results in Tables 1-5, all points have a high SBE 
value. The line with the beauty of Sara island beach's beautiful stretch with views of the city of Lirung island in front of it also adds to its beauty. This assessment is in line with the percentage of evaluations by respondents (26\%). These results indicate that the object is the most chosen as the most beautiful.

Local tourists like Sara Besar's island beach attraction because this tourist attraction provides natural beauty and comfort from the combination of sunshine, sea, and clean white sand beaches. This will be more meaningful with the concept of coastal tourism (coastal tourism) related to tourism activities with fun things and recreational activities carried out in coastal areas and waters. Therefore, Sara Besar Island has become a favorite tourist attraction for the people of Talaud Regency.

\section{CONCLUSIONS}

Based on the results of the research that has done, it can conclude that the Scenic Beauty Estimation (SBE) method shows that the results of observations at five (5) points spread across the island of Sara Besar, at point 5 show a value of 226 , where this observation location predominantly has white sandy beach conditions with a sloping beach morphology whereas, at the first observation point it offers a value of 175 , and sequentially for points 2 and 3 have the same value of 219 then for point 4 it has a value of 205 . The results of observations with the SBE (Scenic Beauty Estimation) method on Sara Besar Island are very suitable for coastal tourism activities, as evidenced by the relatively high scores for all landscape photos assessed by respondents.

\section{E. REFERENCES}

BIG. (2015). Pentingnya Informasi Geospasial untuk Menata Laut Indonesia.

CEA. (2018). Trends in Marine Resources and Fisheries Management in Indonesia. Review.

Daniel, T. C., \& Boster, R. S. (1976). Measuring landscape esthetics: the scenic beauty estimation method. USDA Forest Service Research Paper.

Daniel, T. C., \& Schroeder, H. W. (1979). Scenic beauty estimation model: Predicting perceived beauty of forest landscapes. Our Landscape. A Conference on Applied Techniques for Analysis and Management of the Visual Resource.

DLPF - The David and Lucile Packard Foundation. (2015). Indonesia Fisheries: 2015 Review. California Environmental Associates.

Fadlin, F., \& Marfai, M. A. (2016). POTENSI WISATA DAN PREFERENSI VISUAL LANSKAP WISATAWAN UNTUK PENGEMBANGAN PARIWISATA PESISIR (KASUS : PANTAI ANGIN MAMIRI DAN TANJUNG BAYANG KOTA MAKASSAR). Majalah Geografi Indonesia. 
https://doi.org/10.22146/mgi.1561 3

Farizal, O., Harahaf, H., \& Zahra, M. (2020). Perencanaan Lanskap dan Strategi Pengembangan Potensi Daya Tarik Ekowisata Batu Rongring Taman Nasional Gunung Leuser. Jurnal Serambi Engineering.

https://doi.org/10.32672/jse.v5i2.1 928

Gandy, R., \& Meitner, M. J. (2007). The effects of an advanced traveler information system on scenic beauty ratings and the enjoyment of a recreational drive. Landscape and Urban Planning. https://doi.org/10.1016/j.landurbpla n.2007.01.018

IDA. (2020). Oceans, Fisheries and Coastal Economies.

Khakhim, N., Soedharma, D., Mardiastuti, A., Siregar, V. P., \& Boer, M. (2008). Analisis Preferensi Visual Lanskap Pesisir Daerah Istimewa Yogyakarta untuk Pengembangan Pariwisata Pesisir Menuju pada Pengelolaan Wilayah Pesisir Berkelanjutan. Forum Geografi. https://doi.org/10.23917/forgeo.v2 2i1.4925

Koondoko, Y. Y. F., Darma Putra, I. N., \& Paturusi, S. A. (2017). PENGEMBANGAN

PARIWISATA KABUPATEN KEPULAUAN TALAUD PROVINSI SULAWESI UTARA. Jurnal Master Pariwisata (JUMPA).

https://doi.org/10.24843/jumpa.201

7.v04.i02.p09

Kumaat, J., \& Wullur, M. (2017). Analisis Ekonomi dan Daya Dukung Kawasan Ekowisata Pulau Kecil: Studi Kasus Pulau Mahoro
Kabupaten Kepulauan Sitaro. Zenodo.

Morin, K. M. (2009). Landscape Perception. In International Encyclopedia of Human Geography. https://doi.org/10.1016/B978008044910-4.00464-8

Muhamad, S. V. (2014). Indonesia Menuju Poros Maritim Dunia. Info Singkat Hubungan Internasional.

Patrianti, T., Bajari, A., Agustin, H., \& Bakti, I. (2020). Climate Change Communication on Mitigation Policy and Its Challenges Towards Sustainable Development Goals (SDGs). International Journal of Advanced Science and Technology.

Riansyah, A., Aliya, M. R., \& Nahumariri, G. G. N. G. (2019). Analysis of Multipurpose Container-Passenger Vessel (MCPV) with Detachable Superstructure to Improve InterIsland Access in Talaud Island. Jurnal Transportasi Multimoda. https://doi.org/10.25104/mtm.v17i 2.1322

Wijayanto, D., Triarso, I., Nur Taufiq, S. P. J., \& Sugianto, D. N. (2019). Strategies of Marine Tourism Development in Talaud Islands Regency, Indonesia. In IOP Conference Series: Earth and Environmental Science. https://doi.org/10.1088/17551315/246/1/012009

Zhang, F., Zhou, B., Liu, L., Liu, Y., Fung, H. H., Lin, H., \& Ratti, C. (2018). Measuring human perceptions of a large-scale urban region using machine learning. Landscape and Urban Planning. https://doi.org/10.1016/j.landurbpla n.2018.08.020 